\title{
Do Karst Rivers “deserve" their own biotic index? A ten years study on macrozoobenthos in Croatia
}

\author{
Biljana Rađa and Sanja Puljas
}

\begin{abstract}
:
Rađa B., Puljas S. 2010. Do Karst Rivers "deserve" their own biotic index? A ten years study on macrozoobenthos in Croatia. International Journal of Speleology, 39 (2), 137-147. Bologna (Italy). ISSN 0392-6672.

In this study we present the results of a ten year survey of the aquatic macroinvertebrate fauna along four karst rivers: Jadro, Žrnovnica, Grab and Ruda, all of them situated in the Middle Dalmatia region of Croatia, in an attempt to construct the lliric Biotic Index, which will be more applicable for the water quality analysis than the most frequently applied biotic index in Croatia, the Italian Modification of Extended Biotic Index. The rivers geologically belong to the Dinaric karst, unique geological phenomena in Europe. Benthic macroinvertebrates were collected along each river at 15 sites by standard methods of sampling along with several physicochemical parameters, including: temperature, dissolved oxygen, carbon dioxide, alkalinity, hardness and $\mathrm{pH}$. Univariate and multivariate techniques revealed differences in the macroinvertebrate community structure as well as in physicochemical parameters between the Karst rivers and continental rivers. Based on those differences, the lliric Biotic Index was proposed as the standard of karst river water quality in Croatia in accordance with the EU Water Framework Directive. Differences between the lliric Biotic Index and the most commonly used biotic indices in the European Community and the USA (The Biological Monitoring Working Party (B.M.W.P.) scores, i.e. Extended Biotic Index, Indice Biotique, Family Biotic Index) suggest that karst rivers need a new biotic index.
\end{abstract}

Keywords: macroinvertebrates, karst rivers, lliric Biotic Index, Croatia, Middle Dalmatia

Received 10 January 2010; Revised 3 April 2010; Accepted 20 June 2010

\section{INTRODUCTION}

It is well known that benthic macroinvertebrates are the best studied faunal community of running waters. Over two decades ago there were at least 19 biotic indices in use all over the world based on macroinvertebrate bottom fauna (Washington, 1984). A review of biological methods applied in the monitoring of rivers in European countries reveals that indices of macroinvertebrate communities are one of the most widely used tools in the biological assessment of rivers. The studies which enable biotic index definition deal mostly with the macrozoobenthic community structure over a long time period to determine the dynamics of physicochemical parameters and their influence on freshwater biota (Fleituch et al., 2002; Fleituch, 2003; Buffagni et al., 2004; Munné \& Prat, 2004; Artemiadou \& Lazaridou, 2005; Gabriels et al., 2005). In Belgium there is the Belgian Biotic Index (De Pauw \& Vanhooren, 1983), in Denmark the Saprobity Index (Pantle \& Buck, 1955), in France the Global Biotic Index or IBGN (AFNOR, 1992); in Germany the Saprobity Index (Knöpp, 1954; Pantle \& Buck, 1955); in Ireland the Quality Rating System (Flanagan \& Toner, 1972); in Italy the Extended Biotic Index

University of Split, Faculty of Science, Department of Biology,

Teslina 12/III, 21000 Split, Croatia. tel.: +385 21385 133, fax: +385 21385 431, e-mail: radja@pmfst.hr, spuljas@pmfst.hr
(IBE) (Ghetti, 2001); in Luxembourg the Biotic Index (Verneaux \& Tuffery, 1968); in the Netherland the Quality Index (K135) (Tolkamp \& Gardeniers, 1988); in Spain the modified Biological Monitoring Working Party (B.M.W.P.) (Alba - Tercedor \& Sanchez - Ortega, 1988) and in Great Britain the Average Score Per Taxon (ASPT) and B.M.W.P. (Armitage et al., 1983). Simić \& Simić (1999) described the Balkan Biotic Index (BNBI) as the result of investigations on the Dunav river and its tributaries. In Croatia, the most applicable biotic indices were the Extended Trent Biotic Index (Ghetti, 2001) and the Saprobity Index (Pantle \& Buck, 1955), used on continental rivers and Mediterranean rivers, including the karst ones. The national standard, which would reflect the water quality based on the specific composition of the benthic community, was not done. Therefore, biotic indices from Western or Central Europe must be used with reserve. The purpose of this investigation was to define a macrozoobenthos based biotic index that would reflect water quality and specific structure of the macroinvertebrate community for Karst Rivers in Croatia. Fauna surveys confirmed that the macrozoobenthic community of those rivers is composed of some different taxa in comparison to continental rivers in Croatia, especially some endemic taxa whose indicator values are unknown (Previšić et al., 2007; Kučinić \& Malicki, 2001; Žganec \& Gottstein, 2009). Known physicochemical parameters show that the concentration of $\mathrm{CO}_{2}$ is higher in the upstream 
parts of karst rivers due to permanent groundwater flow. Those values are extremely high during winter season due to a high level of groundwater. Moreover, other physico-chemical characteristics show that the most water sources in Dalmatia are safely below the international permissible limits and the groundwaters and springs are less polluted than surface waters. The pollutants include various agriculture agents which increase the concentration of nitrite, nitrate, phosphate and sulphate. Bacterial pollution is present in rivers parts where there is no wastewater system (Stambuk-Giljanović, 2005). The aim of this paper is to present the collected data of the community composition and diversity of macroinvertebrates as well as the differences among distinct sectors of the investigated rivers.

Three European and one American biotic indices were applied: B.M.W.P. (Chesters, 1980), Extended Biotic Index (Ghetti, 2001), Indice Biotique (Vernaux $\&$ Tuffery, 1968) and Family Biotic Index (Hilsenhoff, 1988). The proposed Iliric Biotic Index (IBI) is presented as a possible new biotic index model, based, so far, on the study results of four karst rivers. However, some ongoing and further investigations could modify this model and make it applicable as a national standard for all karst rivers in Croatia.

\section{Study sites}

\section{MATERIAL AND METHODS}

The Dinaric karst occupies almost $50 \%$ of Croatian territory (Fig. 1A). The investigated rivers Jadro, Žrnovnica, Grab and Ruda (Fig. 1B) are small rivers originating from the underground waters of the dinaric karst. The area consists of four paleo-dynamic and paleo-structural belts and belongs to carbonate rocks and karst phenomena along the Adriatic coast with carbonate forms of the Mesozoic and later (Kuhta, 2002). Those karst rivers were chosen for the study because they have a typical Mediterranean hydrological regime and have been very important sources of drinking water since the Roman times. The catchment area of the rivers is approximately 260 $\mathrm{km}^{2}$, and it is a part of the Cetina river catchment.
The physicochemical characteristics of the Cetina river catchment have been studied by StambukGiljanović (1994, 1998, 2002, 2005). The upper parts have preserved their natural characteristics but the lower parts have been polluted by impact of human activities such as agriculture and various waste waters (Štambuk-Giljanović, 2002). Five sampling sites situated upstream, midstream and downstream at each river were examined. The upstream sites are directly influenced by groundwater, especially during the winter and spring season, whereas the midstream and downstream sites are influenced by agriculture, urban and industrial sources of pollution. The downstream sites of the Žrnovnica and Jadro rivers are influenced by seawater, especially during summer. The macrozoobenthic species from the estuary have not been taken into consideration.

\section{Physicochemical parameters}

Several physicochemical parameters (temperature, dissolved oxygen, dissolved carbon-dioxide, alkalinity, hardness, $\mathrm{pH}$ and substrate) were measured at each station four times per year from 1994 to 2004 (600 measurements total). Temperature, dissolved oxygen, dissolved carbon dioxide and $\mathrm{pH}$ were measured using a digital multimeter (Handylab set Schött) with appropriate probes according to APHA (1995). Surface water was sampled in 1 liter polypropylene sampling bottles for alkalinity (APHA, 1995). The surface water hardness (in German degrees $\left(\mathrm{d}^{\circ} \mathrm{H}\right)$ ) was calculated as the product of alkalinity $\left(\mathrm{mg} \mathrm{CaCO}_{3} / \mathrm{L}\right)$ multiplied by a factor of 2.8. Substrate particle size analysis was determined using a modified Wentworth scale according Bogner (1986) at the Institute of Oceanography and Fisheries in Split, Croatia.

\section{Macroinvertebrates sampling methods}

One sample of benthic macroinvertebrates was taken at each station four times per year from 19942004 (total 600 samples) using a standard pond net (mesh size $500 \mu \mathrm{m}$ ). The fauna attached to stone surfaces (e.g. planarians, gastropods, leeches) was collected by tweezers and, if necessary, scraped with a

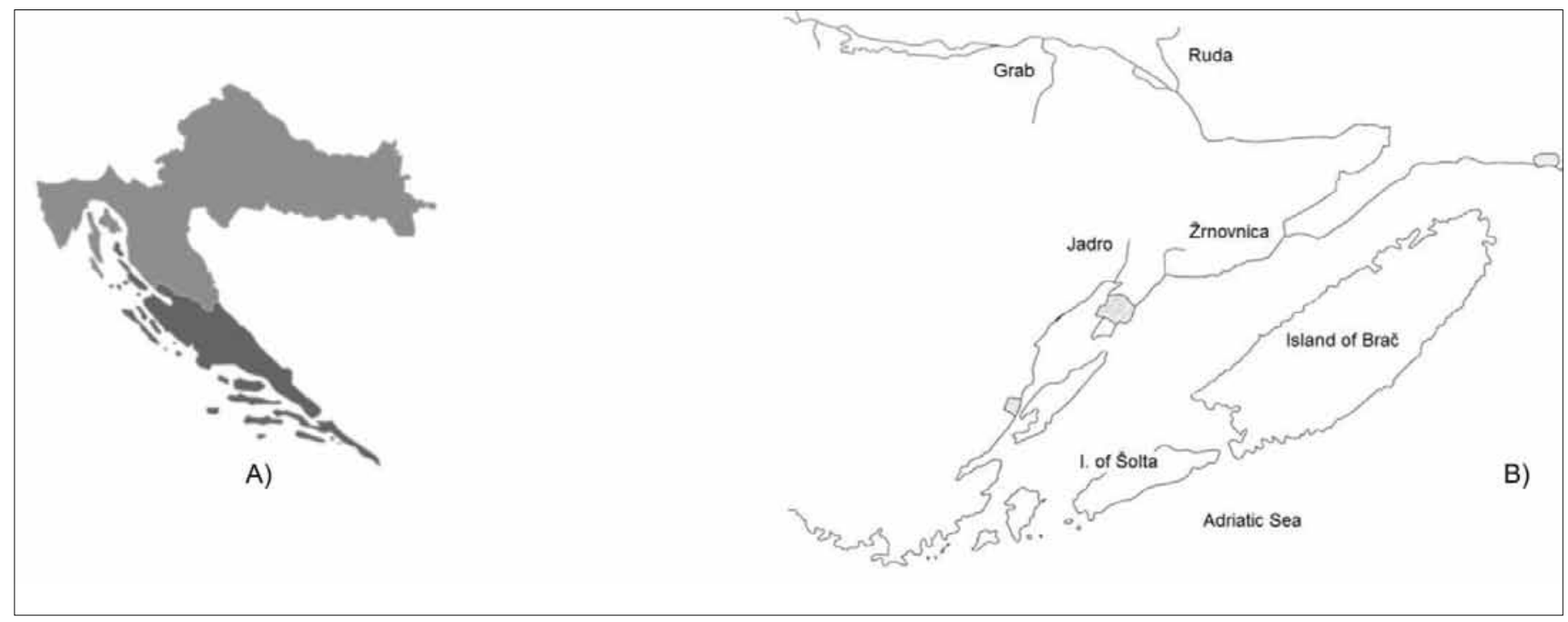

Figure 1. Maps of investigated area: A) Karst area (dark grey), B) Investigated karst rivers. 
fine brush. The samples were placed in plastic bottles and preserved in 95\% ethanol. They were sorted and identification was made to the lowest possible taxonomic level in the laboratory using a stereozoom microscope Leica MZ 7,5 (10x10 and 10x40). The study included qualitative and quantitative analysis of the benthic community using the number of observed taxa, Simpson's Index, Shannon-Weaver Index, Pielou, Margalef's Index (Krebs, 1989) and community abundance. The graphics were made using Primer 5.0 software (Clarke $\&$ Warwick, 2001). The frequency of taxa was calculated as the percentage of taxa in all collected samples. The unweighted pair-group method using arithmetic averages (UPGMA) with Euclidean distance (Krebs, 1989) was used to cluster sites and samples per season. The relationship between the macroinvertebrate taxa and the physicochemical parameters on the one side and sampling sites per year and season were analyzed by Canonical Correspondence Analysis (CCA) using XLSTAT 2010 software. Other graphics were made using Statistica 8.0 software. The complete data set was archived as a part of the Invertebrate Collection at the Department of Biology, Faculty of Science, University of Split.

\section{Biotic scores}

The proposed model of the Iliric Biotic Index, three European: BMWP (Chesters, 1980), EBI (Ghetti, 2001; Woodiwiss 1978, 1980), IBGN (Vernaux \& Tuffery, 1968) and one American FBI (Hilsenhoff, 1988) biotic index scores were applied to the samples.

According to presented data the proposed Iliric Biotic Index (IBI) could be the combination of three metrics: 1- The relative abundance of taxa (RA - the number of taxa/total number of taxa in a sample); 2Biotope quality (BQ) based on the Shannon-Weaver Index sample diversity at the family group level; and 3- Groups (G) of invertebrates according to organic pollution tolerance values, from 0-5 (Table 1). The pollution categories include the following: 0 - 1.5 very heavily polluted; $1.6-3.5$ - polluted; $3.6-4.5$ - clean waters $4.66-5.5$ - streams. (IBI) is calculated as the mean of the three metrics on a scale $0-5.5$.

\section{RESULTS}

The granulometric analysis confirmed that the bottom substrate of upstream stations of all investigated rivers is characterized by $85 \%$ coarse gravel material (4-64 mm grain size) and $14 \%$ cobble (64-256 mm grain size), with substrate size declining downstream (Table 2). The mean values of the water temperature varied from $10.6{ }^{\circ} \mathrm{C}$ (upstream sites during the winter season) to $22.0{ }^{\circ} \mathrm{C}$ (downstream sites during the summer season) following seasonal changes in the air temperature but with slow warming up and cooling. The mean air temperatures show the characteristics of dry Mediterranean climate with values varying from $8.6^{\circ} \mathrm{C}$ (winter) to $28.0^{\circ} \mathrm{C}$ (summer). Spring and autumn values are mainly equal because there is no big difference between those two seasons in

Table 1. Groups and their characteristics according to saprobity level.

\begin{tabular}{|c|c|}
\hline GROUP & characteristics \\
\hline $0-1$ & $\begin{array}{c}\text { no dominant species, } \\
\text { low biodiversity, } \\
1-2 \text { specimens of other group in sample. }\end{array}$ \\
\hline 1 & $\begin{array}{c}\text { dominant group is family Chironomidae (more than } 100 \text { specimens in sample) } \\
\text { family Tubificidae (Naididae) - Oligochaeta } \\
\text { family Psychodidae- Diptera }\end{array}$ \\
\hline 2 & $\begin{array}{c}\text { Ephemeroptera (Baetidae - Cloeon, Caenidae - Caenis) } \\
\text { Trichoptera (Hydropsichidae) } \\
\text { Chironomidae (Chironomus- dominant taxon) } \\
\text { Isopoda (Asellidae - Asellus aquaticus) } \\
\text { Mollusca * } \\
\text { family Tubificidae (Naididae- Nais - dominant taxon) - Oligochaeta } \\
\text { Hirudinea (Erpobdellidae). }\end{array}$ \\
\hline 3 & $\begin{array}{c}\text { Mollusca (Lymneidae, Viviparidae,Neritidae - Theodoxus, Bythiniidae - Bythinia) } \\
\text { Ephemeroptera (Ephemerellidae - Ephemera, Heptageniidae - Heptagenia, Caenidae - Caenis, Baetidae - Cloeon, Baetis) } \\
\text { Odonata* } \\
\text { Trichoptera (Hydropsichidae and Limnephilidae) } \\
\text { Chironomidae without Tanytarsus and Tanypus } \\
\text { Diptera (Simuliidae and other taxons, except Psychodidae) } \\
\text { Heteroptera* } \\
\text { Amphipoda (Gammaridae- Gammarus - the most dominant taxon) } \\
\text { Oligochaeta without Nais }\end{array}$ \\
\hline 4 & $\begin{array}{c}\text { Turbellaria* } \\
\text { Mollusca* } \\
\text { Oligochaeta (Eiseniella, Lumbriculus) } \\
\text { Hirudinea (all families except Erpobdellidae) } \\
\text { Amphipoda (Gammaridae) } \\
\text { Plecoptera (Perlidae - Perla, Isoperla, Leuctridae - Leuctra) } \\
\text { Ephemeroptera (Heptageniidae - Ecdyonurus, Rhitrogena, Baetidae - Baetis) } \\
\text { Trichoptera (Sericostomtidaea, Rhyacophilidae) } \\
\text { Coleoptera (Elmidae) }\end{array}$ \\
\hline 5 & $\begin{array}{c}\text { Turbellaria * } \\
\text { Ephemeroptera (Baetidae - Baetis) } \\
\text { Trichoptera* } \\
\text { Diptera (Simuliidae - Prosimulium) }\end{array}$ \\
\hline
\end{tabular}

* - macroinvertebrate group with families without indicator values for karst rivers 
Table 2. Granulometric analysis of sampling sites on investigated karst rivers.

\begin{tabular}{|cccc|}
\hline & upstream (\%) & midstream (\%) & downstream (\%) \\
\hline cobble (64-256) & 14 & 3,5 & 70,5 \\
\hline coarse gravel (4-64) & 85 & 93,5 & 7,5 \\
\hline very fine gravel (2-4) & 1,5 & 1,5 & 22 \\
\hline & 0,5 & 1,5 & \\
\hline
\end{tabular}

Mediterranean area, including Middle Dalmatia (Fig. $2 \mathrm{~A})$. The mean values of dissolved oxygen at upstream sites varied from $4.0 \mathrm{mg} / \mathrm{L}$ (winter) to $12.5 \mathrm{mg} / \mathrm{L}$ (spring). Dissolved oxygen saturation ranged from $36 \%$ to $115 \%$. The mean values at midstream sites varied from $6.8 \mathrm{mg} / \mathrm{L}$ (winter) to $14.7 \mathrm{mg} / \mathrm{L}$ (spring), whereas the downstream site dissolved oxygen values ranged from $3.1 \mathrm{mg} / \mathrm{L}$ (winter) to $7.5 \mathrm{mg} / \mathrm{L}$ (spring). A higher concentration of carbon dioxide was measured during winter season at upstream $(11.8 \mathrm{mg} / \mathrm{L})$ and midstream sites $(9.5 \mathrm{mg} / \mathrm{L})$. At downstream sites on the Jadro and Žrnovnica rivers, the carbonate dioxide values were higher than those of dissolved oxygen in each season $(7.4 \mathrm{mg} / \mathrm{L}-23.79 \mathrm{mg} / \mathrm{L})$. An extremely high value $(23.79 \mathrm{mg} / \mathrm{L})$ was recorded in summer (high water temperature, low flow and velocity) (Fig. 2B). The hardness and alkalinity show the bicarbonate character of the water. The mean values varied from $150 \mathrm{mg} \mathrm{CaCO} / \mathrm{L}$ (upstream sites) to $255 \mathrm{mg} \mathrm{CaCO}_{3} / \mathrm{L}$ (midstream and downstream sites). The $\mathrm{pH}$ value ranged from 6.8 to 7.8 with upstream sites having higher values (Figs. 3A-C). The CCA analysis (Fig. 4) shows that the total nitrogen and dissolved salts from the agricultural areas are the main components that influenced the macroinvertebrate community at midstream and downstream sites (J2, Z2 and Z3). Those components correlated with the number of specimens in group Turbellaria and decrease their number in the whole sample. $\mathrm{pH}$ is the most stabile parameter. Hardness and the water temperature change seasonally. The group Insecta is dependent on water temperature. Stations J2, Z2 and Z3 have different water chemical composition because of the sea influence. Upstream and midstream stations of the rivers Ruda and Grab shows the great influence of nitrates (from the underground flow as well as from the agricultural surfaces). Nitrate values are in correlation with the increase number of specimens among oligochaetes and leeches. Dissolved oxygen and carbon-dioxide are in correlation due to their antagonistic values. But the $\mathrm{CO}_{2}$ values are in negative correlation with dissolved oxygen on $\mathrm{J} 1, \mathrm{Z} 1$, G1 and R1 stations due to the groundwater influence. Mollusks are the less variant group according their relative abundance due to physicochemical and seasonal changes in rivers. Crustaceans variability is related with water temperature.

During this investigation, 58 macroinvertebrate taxa were identified (Table 3). The main characteristics of the macrozoobenthic community of the investigated karst rivers are as follows. The highest taxa richness was observed among insects (class Insecta), especially mayflies (order Ephemeroptera) with ten species and snails (class Gastropoda) with nine species recorded. Other invertebrate groups were less species rich. Analysis of the macroinvertebrate community by season shows that snails had equal abundance throughout the seasons (app. 50-68\%) at all sampling sites. Three species encountered, Adriohydrobia kutschigi Frfld, Emmericia patula (Brumati 1838) and Oxyloma elegans (Risso, 1826) are endemic and protected by the Law on Protection of Nature of the Republic of Croatia. We also found the most common central European species in continental waters, including Ancylus fluviatilis O.F. Müller, 1774, Physa fontinalis (Linnaeus 1758) and Theodoxus fluviatilis (Linnaeus, 1758). The abundance of amphipods and insects increased in spring and summer $(12 \%$ and $26 \%$, respectively) and decreased in autumn and winter $(6 \%$ and $12 \%)$. The mean value of flatworm abundance is 712 specimens at the upstream sites during the ten year period which is $7.2 \%$ in relation to the total number of specimens in sample. The same species were isolated from the midstream

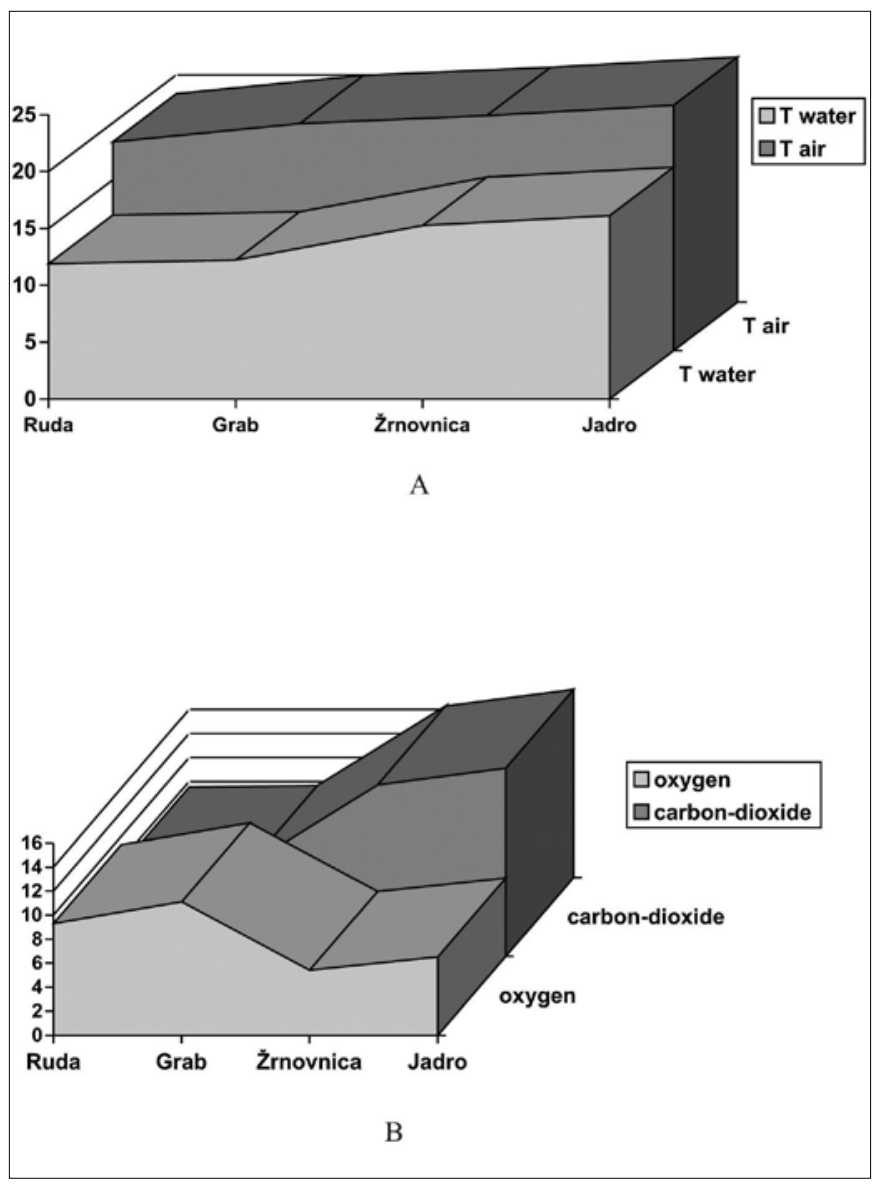

Figure 2. Mean values of water and air temperature at sampling sites in the period from 1994 to 2004 : A) air and water temperature $\left({ }^{\circ} \mathrm{C}\right), \mathrm{B}$ ) dissolved oxygen and carbon-dioxide ( $\mathrm{mg} / \mathrm{L})$. 


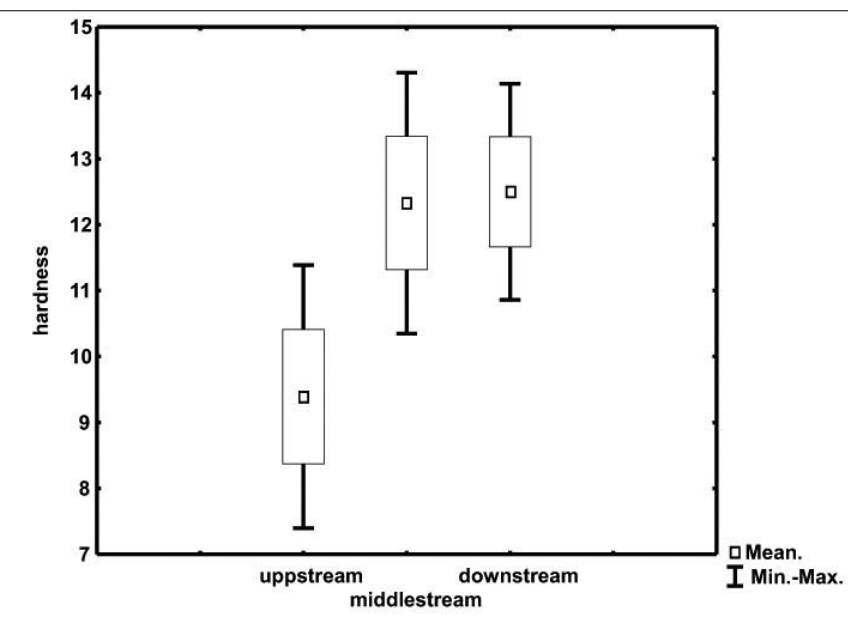

A)

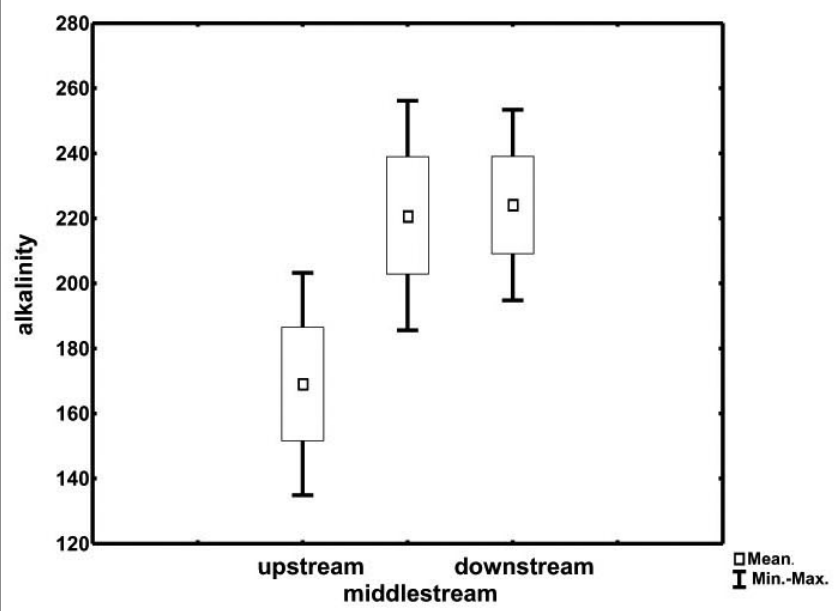

B)

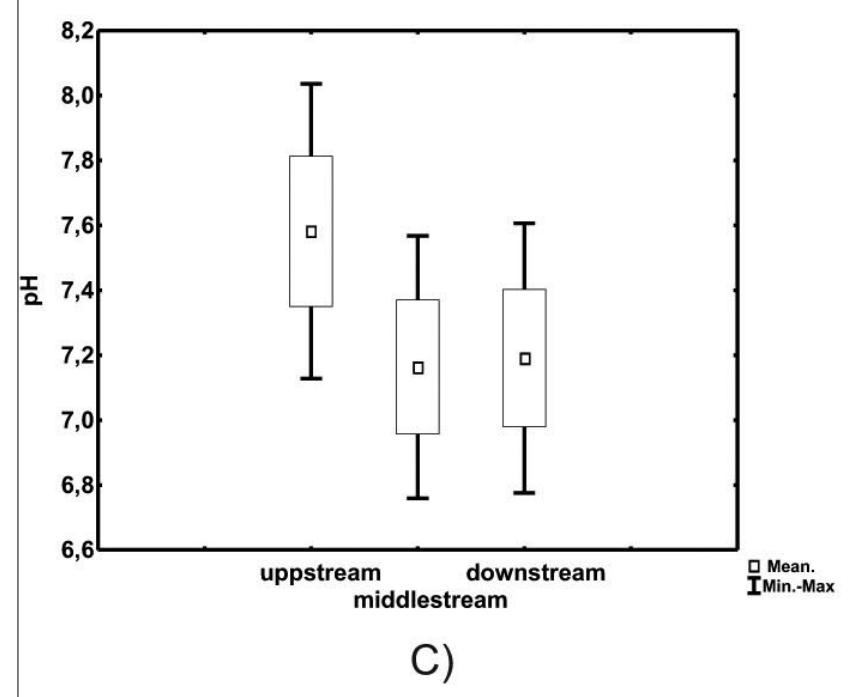

Figure 3. Other measured physicochemical parameters: A) hardness ( $\left.{ }^{\circ} \mathrm{h}\right)$; B) alkalinity (mg/l); C) $\mathrm{pH}$

sites, where the abundance was only 74 specimens total. The Oligochaeta group at the upstream sites is represented by Eiseniella tetraedra (Savigny, 1826) (Lumbricidae), where 352 individuals were recorded (4.67\%). At downstream sites the dominant species were Nais barbata Müller, 1774 (Naididae) and Tubifex tubifex (Müller, 1774) (Tubificidae). The abundance of these species increases downstream according the organic pollution on $8.97 \%$ (Nematodes) and $13.5 \%$ (other Oligochaetes). Two species of leeches (Hirudinea), Erpobdella octoculata (Linnaeus, 1758) and Glossiphonia complanata (L.) are less abundant at upstream sites (3.65\%) in relation to the other Oligochaetes. Helobdella stagnalis (Linnaeus, 1758) was isolated in the middstream area and $G$. complanata at downstream sites. The abundance of the later species in the whole sample was $2.90 \%$ (midstream) and 3.49\% (downstream). The listed taxa appear individually and are formally distributed along the river.

The relation between the numbers of individuals in macroinvertebrate groups through four seasons at upstream sites is shown in Fig. 5A. Ostracods, worms and stoneflies (Plecoptera) were not identified at midstream sites. Gastropods were the dominant group by mean relative abundance and amphipods and insects increased in number throughout spring and summer (Fig. 5B). The downstream macroinvertebrate community differs from those at the upstream and midstream sites in that polychaetes were present, due to the great sea influence on the Jadro and Žrnovnica rivers (Fig. 5C).

The UPGMA analysis confirmed that the downstream sites show the largest dissimilarity in comparison to the upstream and midstream sites (Fig. 6) and the main factor for such distance is the sea influence on the downstream sites of Jadro and Žrnovnica rivers. There is also a bigger dissimilarity between upstream and downstream sites than upstream and midstream sites because the influence of underground waters defines community structure at upstream sites as well as physicochemical parameters. Dissimilarity indices indicate that the species diversity is higher in the upstream and downstream areas of the surveyed rivers. The species diversity at the upstream sites increased between 1994 and 1998 and 1999 - 2002 and for midstream sites the disimilarity indices were almost equal. The indices on downstream sites showed unequal values (Table 4). The Sorensen's index indicated similarity of 85,7 \% for upstream and midstream sites, 70,27 \% between midstream and downstream sites and 55,26\% between upstream and downstream sites (Table 5). The values of different indices and biotic scores including the values of the IBI with water quality classes (Roman numerals) are shown in Table 6.

Person's coefficient between other biotic indices and the IBI scores was variable (Table 7 ). The relation between the BMWP and IBI shows a statistically significant positive correlation, though the statistical significant shows only five percents of sample recognition and thus BMWP is not appropriate to define the water quality on karst rivers based on the IBI. The relation between the EBI and IBI shows a statistically significant negative correlation because of the different scale of pollution categories. The statistical significant show over $38 \%$ of sample recognition and thus the $\mathrm{EBI}$ is more applicable to karst rivers than the IBI. The relation between the FBI and IBI is statistically significant and shows 


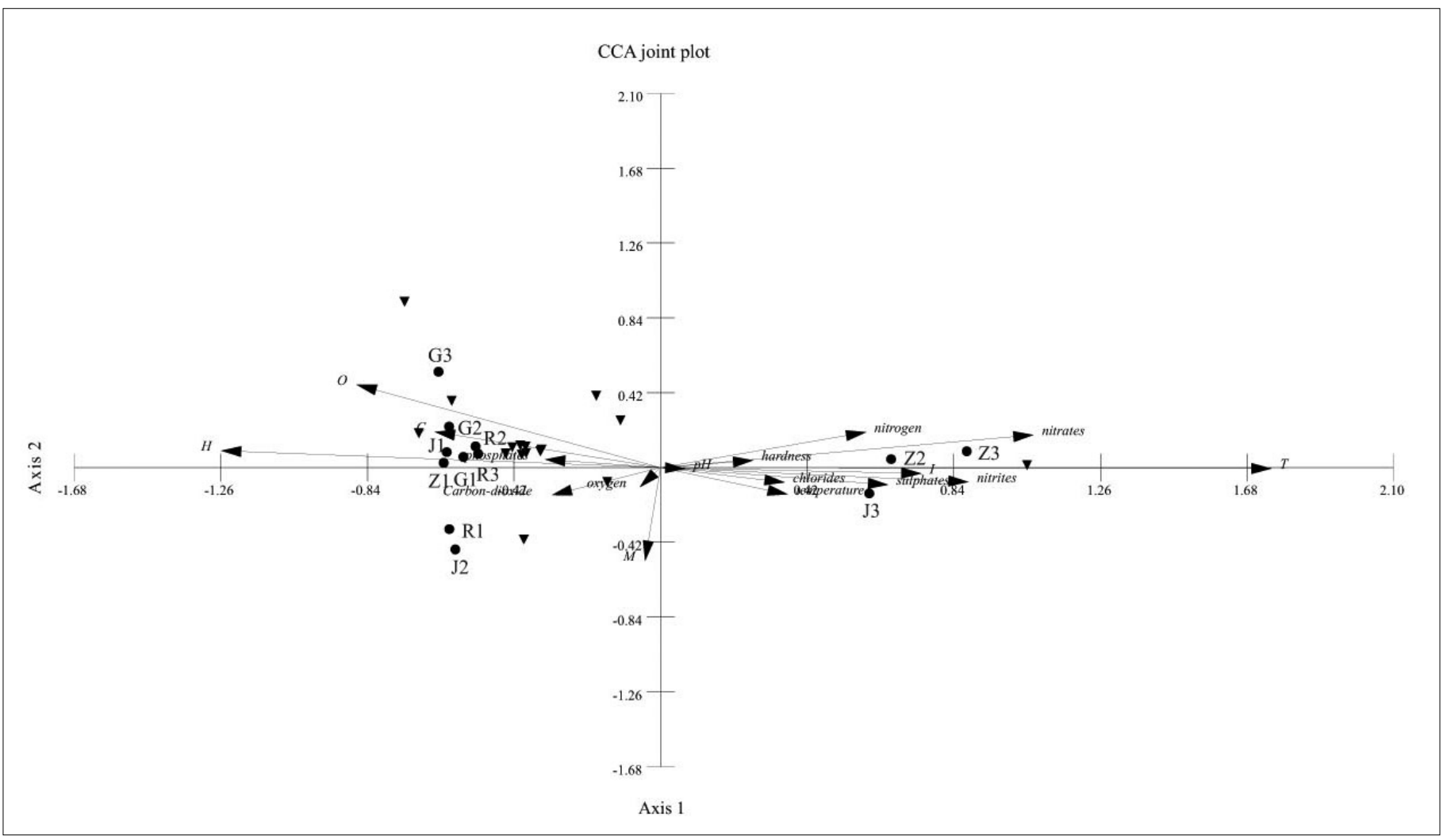

Figure 4. The ordination diagram of CCA analysis

Table 3. Composition of the benthic fauna of the karst rivers during the period of investigation (1994-2004).

\begin{tabular}{|c|c|}
\hline TURBELLARIA & EPHEMEROPTERA \\
\hline Polycelis felina & Baetis sp. \\
\hline Dugesia gonocephala & Baetis rhodani \\
\hline NEMATODA & Centroptilum luteolum \\
\hline Nematoda & Cloeon simile \\
\hline OLIGOCHAETA & Ecdyonurus sp. \\
\hline Limnodrilus sp. & Ephemera danica \\
\hline Nais sp. & Ephemerella sp. \\
\hline Tubifex sp. & Ephemerella ignita \\
\hline OLIGOCHAETA-ANNELIDA & Heptagenia sulphurea \\
\hline Eiseniella tetraedra & Rhithrogena sp. \\
\hline Lumbricus rubellus & PLECOPTERA \\
\hline OLIGOCHAETA-HIRUDINEA & Capnia sp. \\
\hline Erpobdella octoculata & Chloroperla sp. \\
\hline Glossiphonia complanata & Perla bipunctata \\
\hline Helobdella stagnalis & ODONATA \\
\hline GASTROPODA & Anax imperator \\
\hline Adriohydrobia kutschigi & Calopterix virgo \\
\hline Ancylus fluviatilis & Cordulegaster boltoni \\
\hline Costellina turrita & Rhynosoma sp. \\
\hline Emmericia patula & TRICHOPTERA \\
\hline Iglica elongata & Agapetus sp. \\
\hline Lanzaia sp. & Glossosoma boltoni \\
\hline Lymnea stagnalis & Hydropsyche sp. \\
\hline Oxyloma elegans & Limnephilus sp. \\
\hline Physa fontinalis & Odontocerum albicorne \\
\hline Theodoxus fluviatilis & Polycentropus flavomaculatus \\
\hline \multicolumn{2}{|l|}{ BIVALVIA } \\
\hline Pisidium sp. & COLEOPTERA \\
\hline Sphaerium sp. & Elmis sp. \\
\hline
\end{tabular}




\begin{tabular}{|c|c|}
\hline CRUSTACEA & DIPTERA \\
\hline Asellus aquaticus & Ablabesmyia sp. \\
\hline Gammarus balcanicus & Dixa sp. \\
\hline OSTRACODA & Chironomus $s p$. \\
\hline Cypris sp. & Simulium sp. \\
\hline ACARINA & Tanypus sp. \\
\hline Hygrobates sp. & POLYCHAETA \\
\hline Neumania apinipes & Heteronereis sp. \\
\hline
\end{tabular}
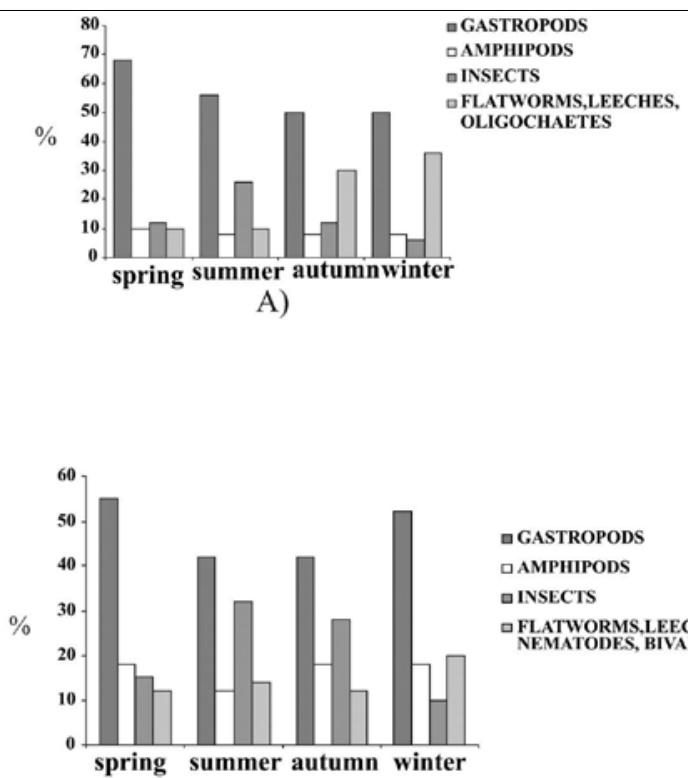

¿GASTROPODS 口AMPHIPODS $\square$ INSECTS 口 FLATWORMS,LEECHES,

B)

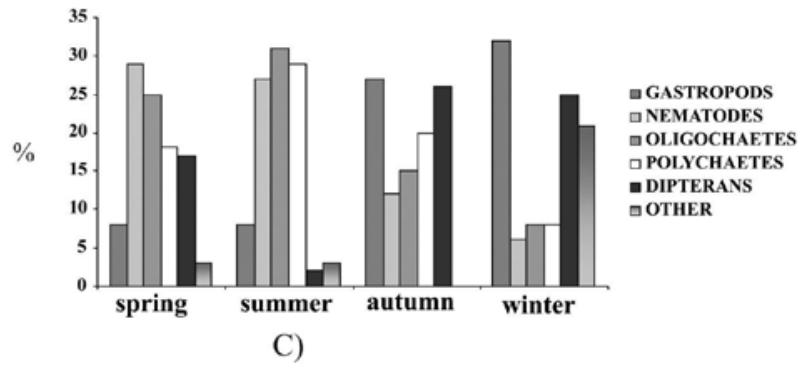

Figure 5. Relative abundance of macroinvertebrate groups at sampling sites per season: A) upstream sites; B) midstream sites; C) downstream sites.

negative correlation. The statistical significant shows only two percents of sample recognition because the macroinvertebrate fauna of North America and Croatian karst rivers fauna are quite different. Thus, the FBI is not appropriate to define the water quality of the karst rivers. The relation between the IBGN and IBI is statistically significant and exhibits negative correlation. The statistical significant show only one percent of sample recognition and therefore the IBGN is not appropriate to define the karst water quality.

To test the significance of IBI in different river conditions we calculated IBI before and nearly after ecological incident who took place on the river Jadro at 2002 (Table 8). The decrease value from 3,856 (clean natural waters) before incident on 1,182 (very havily polluted) after incident is an evidence that IBI model is able to detect changes in macrozoobenthos community of karst rivers.

\section{DISCUSSION}

Mollusks, amphipods and insects were the principal components of the community with regard to number of identified species, frequency of occurrence, as well as with regard to relative abundance in the karst rivers in Croatia. This is a quite different community structure from that of the continental rivers in Croatia in which chironomids and oligochaetes are the principal components (Mihaljević et al., 1998; Habdija et al., 2003). Investigations of the macroinvertebrate community on other karst rivers in continental Croatia show the community structure similar to those of the Mediterranean karst rivers, but the continental karst rivers share general taxonomic groups (Mihaljević et al., 1998; Habdija et al., 2003; Radanović et al., 2006). Previous surveys of the Jadro, Žrnovnica, Grab and Ruda rivers found fewer taxa with similar abundance of mollusks, amphipods and insects through seasons (Vuković, 1981; Apostolska, 1988; Kerovec, 1996; Rađa 2002, 2006). The physicochemical parameters greatly influences the structure and abundance of macrozoobenthic community in rivers (Flanagan \& Toner, 1972; Moss et al., 1987; Rosenberg \& Resh, 1993; Clarke et al., 2002; Boyle \& Fraileigh, 2003; Fleituch, 2003; Nedeau et al., 2003; Neumann et al. 2003a, 2003b). The macroinvertebrate community structure and abundance change seasonally and depend on the sampling site Fleituch (2003). In Croatian karst rivers, the most numerous group was snails (Gastropoda) followed by amphipods and insects. A considerable increase in the abundance of amphipods and insects was observed in spring and summer, as supported by previous investigations (Vuković, 1981; Apostolska, 1988; Kerovec, 1996; Rađa 2002, 2006). The qualitative sample of the River Žrnovnica, which is hydrologically connected by the underground flow with the river Jadro (Bonacci, 1978), showed no differences in composition of taxonomic groups or in macrozoobenthic species. The reduction in the number of flatworms from upstream to downstream sites results from the change of the habitat conditions showing lower values of dissolved oxygen and higher water temperature, both being limiting conditions for certain species. One family of bivalves (Sphaeriidae) was represented with two genera: Pisidium and Sphaerium. The species of both genera are widely distributed and appear most frequently on fine substrate such as fine gravel or sand 


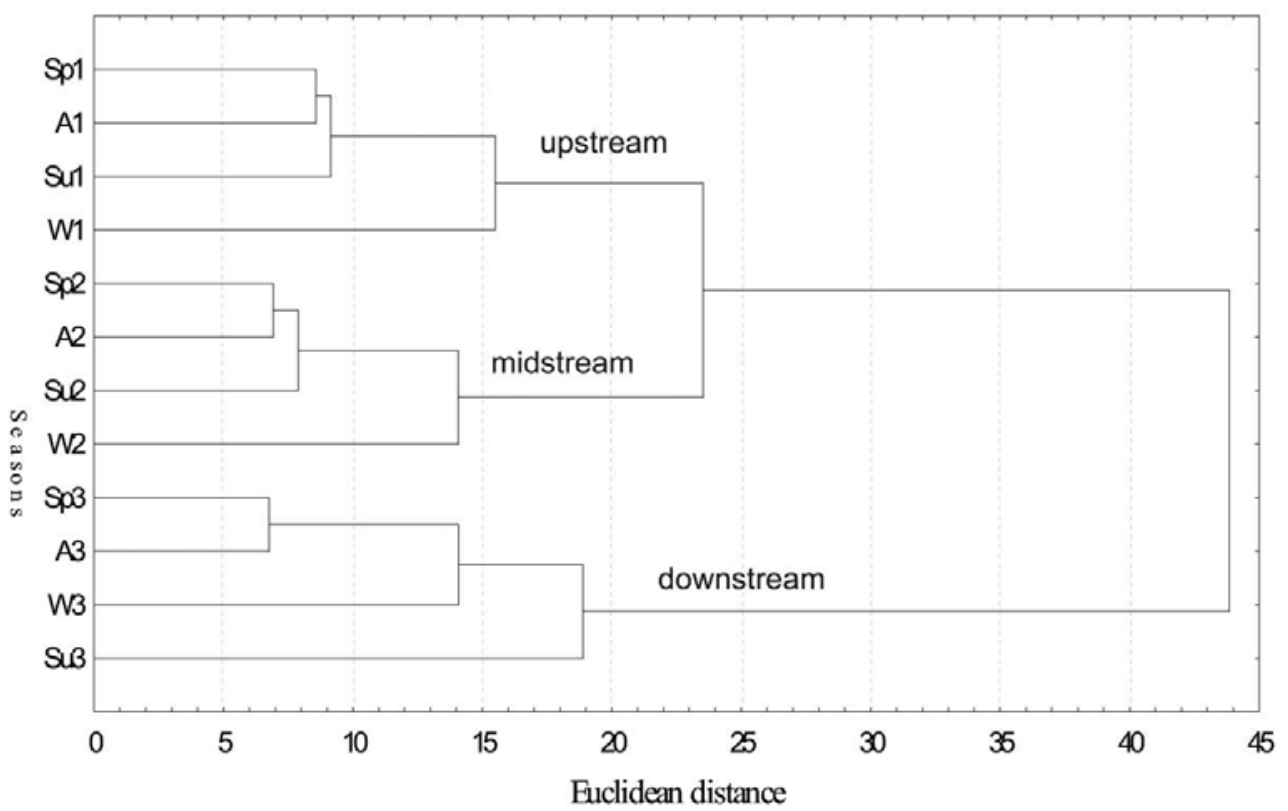

Figure 6. UPGMA analysis between areas according community structure and physicochemical parameters at sampling sites through seasons: 11 - A3 - autumn; W1 - W3 - winter; Sp1 - Sp3 - spring; Su1 - Su3 - summer.

Table 4. Dissimilarity indices for research period (d=Margalef's index, J'=Pielou index, H'=Shannon-Weaver index, $1-\lambda=$ Simpson's index).

\begin{tabular}{|c|c|c|c|c|c|c|c|c|c|c|c|c|}
\hline & \multicolumn{4}{|c|}{ upstream sites } & \multicolumn{4}{|c|}{ midstream sites } & \multicolumn{4}{|c|}{ downstream sites } \\
\hline & $\mathrm{d}$ & $J^{\prime}$ & $\mathrm{H}^{\prime}$ & $1-\lambda$ & $d$ & J' & $\mathrm{H}^{\prime}$ & $1-\lambda$ & $d$ & $J^{\prime}$ & $H^{\prime}$ & $1-\lambda$ \\
\hline 1994. & 1.99 & 0.81 & 2.15 & 0.83 & 2.21 & 0.63 & 1.66 & 0.68 & 1.92 & 0.80 & 2.11 & 0.84 \\
\hline 1995. & 2.01 & 0.88 & 2.32 & 0.86 & 1.71 & 0.72 & 1.72 & 0.74 & 1.77 & 0.82 & 2.11 & 0.84 \\
\hline 1996. & 2.03 & 0.90 & 2.40 & 0.88 & 2.12 & 0.63 & 1.68 & 0.69 & 1.79 & 0.83 & 2.13 & 0.85 \\
\hline 1997. & 1.97 & 0.80 & 2.11 & 0.80 & 2.10 & 0.62 & 1.65 & 0.69 & 1.90 & 0.81 & 2.15 & 0.85 \\
\hline 1998. & 2.00 & 0.84 & 2.22 & 0.83 & 2.04 & 0.63 & 1.62 & 0.67 & 1.91 & 0.82 & 2.16 & 0.85 \\
\hline 1999. & 1.96 & 0.78 & 2.06 & 0.78 & 1.97 & 0.65 & 1.67 & 0.68 & 1.77 & 0.81 & 2.09 & 0.84 \\
\hline 2000. & 1.98 & 0.84 & 2.23 & 0.83 & 2.08 & 0.59 & 1.56 & 0.65 & 1.79 & 0.86 & 2.21 & 0.86 \\
\hline 2001. & 2.01 & 0.87 & 2.31 & 0.86 & 2.00 & 0.67 & 1.72 & 0.71 & 1.89 & 0.79 & 2.09 & 0.84 \\
\hline 2002. & 1.95 & 0.78 & 2.07 & 0.79 & 1.81 & 0.59 & 1.48 & 0.62 & 1.76 & 0.84 & 2.16 & 0.85 \\
\hline 2003. & 1.93 & 0.80 & 2.13 & 0.81 & 1.76 & 0.55 & 1.37 & 0.57 & 1.76 & 0.82 & 2.11 & 0.84 \\
\hline 2004. & 1.99 & 0.78 & 2.07 & 0.78 & 1.90 & 0.67 & 1.67 & 0.70 & 1.88 & 0.82 & 2.17 & 0.85 \\
\hline$M$ & 1.98 & 0.82 & 2.18 & 0.82 & 1.97 & 0.63 & 1.61 & 0.67 & 1.83 & 0.82 & 2.13 & 0.84 \\
\hline
\end{tabular}

Note: Samples were collected in a ten years period. Values present the arithmetic mean (M).

Table 5. Sørensen's index (QS - Sørensen's index, a- total number of species in first sample, b- total number of species in second sample, c number of common species in two samples).

\begin{tabular}{|c|c|c|c|c|}
\hline SAMPLING SITES & a & b & QS \\
\hline upstream - midstream & 36 & 43 & 41 & $85,70 \%$ \\
midstream - downstream & 26 & 41 & 33 & $70,27 \%$ \\
upstream - downstream & 21 & 43 & 33 & $55,26 \%$ \\
\hline
\end{tabular}

Table 6. The values of tested indices with water quality classes (IBI-lliric Biotic Index; BMWP-Biological Monitoring Working Party; EBI - Extended otic Index; FBI - Family Biotic Index; IBGN - Indice Biotique).

\begin{tabular}{|c|c|c|c|c|c|}
\hline Karst rivers & $|\mathrm{B}|$ & BMWP & EBI & FBI & IBGN \\
\hline Jadro & 4,97 / II & $43 / \mathrm{III}$ & 9/ II-III & $5,64 / \mathrm{II}-\mathrm{III}$ & $12 /||-|| \mid$ \\
\hline Žrnovnica & $2,7 / \mathrm{III}$ & 67 /III & $7 /||-||||$ & $3,84 / I-I I$ & $17 / /-\|$ \\
\hline Grab & $2,78 / \mathrm{III}$ & $18 / I I I$ & $13 / I-I I$ & $3,25 / 1$ & 4/ III - IV \\
\hline Ruda & $2,82 / \mathrm{III}$ & 19/III & $8 / I I-I I I$ & $6,87 / \mathrm{III}-\mathrm{IV}$ & $3 / I I I \mid-I V$ \\
\hline
\end{tabular}


Table 7. Pearson's coefficient of correlation (IBI=Iliric Biotic Index, BMWP= Biological Monitoring Working Party, EBI = Extended Biotic Index, $\mathrm{FBI}=$ Family Biotic Index, IBGN = Indice biotique).

\begin{tabular}{|c|c|c|c|c|}
\hline & $r(x, y)$ & $r^{2}$ & $p$ \\
\hline IBI-BMWP & 0,227 & 0,051 & 0,522 & 0,623 \\
\hline IBI - EBI & $-0,622$ & 0,387 & $-1,777$ & 0,135 \\
\hline IBI - FBI & $-0,170$ & 0,028 & $-0,385$ & 0,715 \\
\hline IBI - IBGN & $-0,136$ & 0,018 & $-0,307$ & 0,770 \\
\hline
\end{tabular}

Table 8. The testing of IBI immediately and three years after pollution on the river Jadro.

\begin{tabular}{|c|c|c|}
\hline & $\mathbf{2 0 0 2}$ & $\mathbf{2 0 0 5 .}$ \\
\hline $\mathbf{S}$ & 0,182 & 1,856 \\
\hline $\mathbf{R}$ & 1 & 2 \\
\hline IBI & 1,182 very heavily polluted & 3,856 clean waters \\
\hline
\end{tabular}

(Burch, 1975) of the same grain size as in the Jadro River. Burch (1975) also found maximum occurrence of Pisidium on the substrate of $0.18 \mathrm{~mm}$ grain size. The number of specimens increased along the stream in areas with greater pebble and cobble substrate as a result of granulometric composition.

The crustaceans were represented with amphipods (Amphipoda), isopods (Isopoda) and ostracods (Ostracoda). With regard to the abundance, isopods are the second most represented group in the whole quality sample. This investigation confirms that crustaceans abundance changes seasonally with highest abundance in spring, summer and the beginning of autumn. It has also been established that their-highest abundance occurs upstream. It is also stated that the abundance of isopods and amphipods is reduced downstream as the result of changed ecological conditions. Six groups of insects were recorded: mayflies (Ephemeroptera), stoneflies (Plecoptera), dragonflies (Odonata), caddisflies (Trichoptera), riffle beetles (Coleoptera) and true flies (Diptera). Mayflies (Ephemeroptera) are represented by 10 different species. The species Baëtis rhodani (Pictet, 1843) and Heptagenia sulphurea (Muller, 1776) were not isolated from the downstream samples. In earlier studies 11 different species were identified, some of which are common in European freshwaters (Di Giovanni et al., 2003). Stoneflies (Plecoptera) were isolated solely from the upstream samples because they develop only in cold, clear springs and are evidently sensitive to low oxygen concentration and organic pollution. Simić \& Simić (1999) mentioned in their surveys of the Serbian freshwaters that all Plecoptera species were found in clear spring waters in the upstream segments of the explored rivers. Di Giovanni et al. (2003) identified the same species in the Chiascio River in Italy, as did Askew (1988) in his list of Odonata for Europe.

The Sørensen's similarity index confirmed a great similarity between the upstream and mid-stream sites, some lower similarity between midstream and downstream sites and the lowest one between upstream and downstream sites. This proportion coincides also with the CCA analysis, so it can be presumed that the macrozoobenthic community of the investigated rivers is the result of established regularity of all measured parameters. The observed changes are more a result of the short term influence of the underground waters, climatic circumstances and influence of the sea downstream than a sign of heavier ecosystem disturbance.

In its conception and mode of use, the presented IBI model is most similar to the BNBI index (1999), but with significant modifications and additions resulting from faunistic specificities of the studied area. Of the published indices, the EBI is the most applicable biotic index for karst rivers in Croatia, probably because of the geological connection between the Italian and Croatian seaside.

Limitations of the IBI model are the inclusion of taxa encountered only once in metric calculation and the inclusion of higher taxonomic categories (i.e. the orders Plecoptera, Ephemeroptera, Trichoptera) without considering the individual species response. For example, Rađa (2006) showed that the macroinvertebrate fauna in karst rivers has a high taxonomic diversity where large numbers of different taxa were found with a small number of individuals per taxa. From the results it is quite obvious that no indices could be directly applied in assessing the water quality of the karst rivers. It confirms the fact that an appropriate biological method based on indices or a score system is possible only when local communities are properly scored. The differences between the IBI and similar indices from western and central Europe are as follows: diversity, which can be used independently as a factor of ecological quality of the habitat, relative abundance in the sample as evidence of community structure and a list of bioindicators according the pollution level specific for karst rivers.

\section{CONCLUSION AND COMMENTS}

Karst rivers in Croatia are a very important part of the Dinaric karst but investigations of macrozoobenthos community were made mostly on continental rivers. The water quality of karst rivers in Croatia was measured mostly using the Extended Biotic Index, 
but it was obvious that the faunal composition of the karst rivers differs from west or central European macrozoobenthos. According to the macrozoobenthic community in karst rivers we propose a new biotic index named Iliric Biotic Index as a model which could be most apropriate for the water quality evaluation because the comparison between IBI and some other biotic indices confirms that european and american indices must be used with the reserve.

\section{REFERENCES}

AFNOR, 1992 - Essais des eaux. Détermination de l'indice biologique global normalisé (IBGN). Norme française, NF T: 90-350.

Alba-Tercedor J. \& Sánchez-Ortega A., 1988 - Un metodo rapido y simple para evoluar le calidad biologica de las aguas corrientes basado en el de Hellawell (1978). Limnetica, 4: 51-56.

APHA, 1995 - Standard Methods for the Examination of Water and Wastewater. American Public Health Association, Washington DC, USA.

Apostolska B., 1989 - Macrozoobenthos and saprobity of The River Jadro. Thesis. Faculty of Natural Science, University of Zagreb, $76 \mathrm{p}$.

Armitage P.D., Moss D., Wright J.F. \& Furse M.T., 1983 - The performance of a new water quality score system based on macroinvertebrates over a wide range of unpolluted running-water sites. Water Research, 17: 333-347.

Artemiadou V. \& Lazaridou M., 2005 - Evaluation score and interpretation index for the ecological quality of running waters in central and northern Hellas. Environmental Monitoring and Assesment, 110: 1 40.

Askew R.R., 1988 - The dragonflies of Europe. Harley Books, Colchester, Essex, 291 p.

Bogner D., 1986 - The surface sediments and their influence on heavy metal distribution in Kaštela Bay. Msc thesis. University of Zagreb, $131 \mathrm{p}$.

Bonacci O., 1978 - Hydrological study of The River Žrnounica. Fundus. Civil engineering institute, Split.

Boyle T.P. \& Fraleigh H.D. Jr., 2003 - Natural and anthropogenic factors affecting the structure of the benthic macroinvertebrate community in an effluentdominated reach of the Santa Cruz River. Ecological Indicators, 3: 93-117.

Buffagni A., Erba S., Cazzola M. \& Lynn Kemp J., 2004 - The AQEM multimetric system for the southern Italian Apennines: assessing the impact of water quality and habitat degradation on pool macroinvertebrates in Mediterranean rivers. Hydrobiologia, 516: 313-329.

Burch J.B., 1975 - Freshwater sphaeriacean clams (Mollusca: Pelecypoda) of North America. United States Environmental Protection Agency. Biota of Freshwater Ecosystems, Identification Manual No. 3, 94 p.

Chesters R.K., 1980 - Biological Monitoring Working Party. The 1978 National Testing Exercise (In: Technical Memorandum No. 18). Department of the Environment.

Clarke K.R. \& Warwick R.M., 2001 - Change in marine communities: an approach to statistical analysis and interpretation $-2^{\text {nd }}$ edition. PRIMER-E. Plymouth.
Clarke R.T., Furse M.T., Gunn R.J.M., Winder J.M. \& Wright J.F., 2002 - Sampling variation in macroinvertebrate data and implications for river quality indices. Freshwater Biology, 47: 1735-1751.

De Pauw N. \& Vanhooren G., 1983 - Method for biological quality assessment of watercourses in Belgium. Hydrobiologia, 100: 153-168.

Di Giovanni M.V., Goretti E., Ceccagnoli D., La Porta G. \& Chiappafreddo U., 2003 - Ephemeroptera and Plecoptera in the Chiascio River (Central Italy) since a dam's building. In: Gaino E. (Eds.) - Research Update on Ephemeroptera \& Plecoptera. University of Perugia: 293-298.

Flanagan P.F. \& Toner P.F., 1972 - Notes on the chemical and biological analysis of Irish River Waters, An Foras Forbatha. Water Research Division, St. Martin's House, Waterloo Road, Dublin, Ireland.

Fleituch T., 2003 - Structure and Functional Organization of Benthic Invertebrates in Regulated Stream. International Review of Hydrobiology, 88 (3-4): 332344.

Fleituch T., Soszka H., Kudelska D. \& Kownacki A., 2002 - Macroinvertebrates as indicators of water quality in rivers: a scientific basis for Polish standard method. Archives of Hydrobiology, 141 (3-4): 225-239.

Gabriels W., Goethals P.L.M. \& De Pauw N., 2005 Implications of taxonomic modifications and alien species on biological water quality assessment as exemplified by the Belgian Biotic Index method. Hydrobiologia, 542: 137-150.

Ghetti P.F., 2001 - Indice biotico esteso (I.B.E.). I macroinvertebrati nel controllo della qualità degli ambiente di acque correnti. Manuale di applicazione. Provincia autonoma di Trento, Trento, 222 p.

Habdija I., Radanović I., Primc-Habdija B., Matoničkin R. \& Kučinić M., 2003 - River discharge regime as a factor affecting the changes in commal feeding group composition of macroinvertebrates on a cobble substrate in Sava Riverunity and function. Biologia, 58: $217-229$.

Hilsenhoff W.L., 1988 - Rapid field assesment of organic pollution with a family-level biotic index. Journal of North American Benthological Society, 7: 65-68.

Kerovec M., 1996 - The biological minimum of the river Jadro. Elaborat, Faculty of Natural Science, University of Zagreb, Zagreb, $25 \mathrm{p}$.

Knöpp H., 1954 - Ein neuer Weg zur darstellung biologischer Vorfluteruntersuchungen, erlautert an einem Gutelangschnitt des Maines. Wasserwirtschaft, 45: 9-15.

Krebs C.J., 1989 - Ecological methodology. Harper \& Row Publishers, New York, 654 p.

Kučinić M. \& Malicky H., 2001 -Rhyacophila dorsalis plitvicensis, a new subspecies (Trichoptera: Rhyacophilidae) from Croatia.. Nova supplementa entomologica, 15: 145-147.

Kuhta M., 2002 - The carst. Natura Croatica, 11 (Suppl.): 4-8.

Mihaljević, Z., Kerovec M., Tavčar V. \& Bukvić I., 1998 Macroinvertebrate community on an artificial substrate in the Sava river: long-term changes in the community structure and water quality. Biologia, 53: 611-620. 
Moss D., Furse M.T., Wright J.F. \& Armitage P.D., 1987 The prediction of the macroinvertebrate fauna of unpolluted running-water sites in Great Britain using environmental data. Freshwater Biology, 17: 41-52.

Munné A. \& Prat N., 2004 - Defining River Types in a Mediterranean Area: A Methodology for the complementation of the EU Water Framework Directive. Environmental Management, 34 (5): 711-729.

Nedeau E.J., Merit R.W. \& Kaufman M.G., 2003 - The effect of an industrial effluent on an urban stream benthic community: water quality us. habitat quality. Environmental Pollution, 123: 1-13.

Neumann, M., Baumeister J., Liess M. \& Schulz R., 2003a - An expert system to estimate the pesticide contamination of small streams using benthic macroinvertebrates as bioindicators, II. The knowledge base of LIMPACT. Ecological Indicators, 2: 391-401.

Neumann M., Liess M. \& Schulz R., 2003b - An expert system to estimate the pesticide contamination of small streams using benthic macroinvertebrates as bioindicators, Part 1. The database of LIMPACT. Ecological Indicators, 2: 379-389.

Pantle R. \& Buck H., 1955 - Die biologische Überwaschung der Gewässer und due Darstellung der Ergebnisse besondere. Mitteleitung im Deutschen Gewässerkundlichen, 12: 135143.

Previšić A., Kerovec M., Kučinić M., 2007 - Emergence and Composition of Trichoptera from karst habitats, Plitvice Lakes Region, Croatia. International Review of Hydrobiology, 92 (1): 61-83.

Radanović I., Habdija I., Primc-Habdija B. \& MatoničkinKepčija R., 2006 -Macrobenthic fauna similarity on a cobble substrate in the Sava River. Periodicum biologorum, 108: 5768.

Rađa B., 2002 - The estimation of damage caused by ecological incident - makrozoobenthos. Elaborat. Croatian Waters, Split, $75 \mathrm{p}$.

Rađa B., 2006 - The influence of biotope conditions on macrozoobenthic community of The River Jadro. $\mathrm{PhD}$ Thesis, University of Zagreb.
Rosenberg D.M. \& Resh V.H., 1993 - Freshwater Biomonitoring and Benthic Macroinvertebrates. Chapmann and Hall, New York, $457 \mathrm{p}$.

Simić V. \& Simić S., 1999 - Use of the river macrozoobenthos of Serbia to formulate a biotic index. Hydrobiologia, 416: 51-64.

Štambuk-Giljanović N., 1994 - Vode Dalmacije. ZJZ Županije splitsko-dalmatinske. Split, 263 p.

Štambuk-Giljanović N., 1998 - Vode Neretve i njezina porječja. Dalmacija papir, Split, 763 p.

Štambuk-Giljanović N., 2002 - Vode Cetine i njezina porječja. Dalmacija-papir, Split, 814 p.

Štambuk-Giljanović N., 2005 - The quality of water resources in Dalmatia. Environmental Monitoring and Assessment, 104: 235-267.

Tolkamp H. \& Gardeniers J., 1988 - The development of biological water quality assesment in the Nederlands. Aquatic Ecology, 22 (1): 87-91.

Verneaux J. \& Tuffery G., 1968 - Méthode de détermination de la qualité biologique des eaux courantes. Exploitation codifiée des inventaires de la faune du fond. Ministeére de l'Agriculture (France). CERAFER, Section Peche et Pisciculture.

Vuković T., 1981 - Hydrobiological conditions of the river Jadro. Elaborat, Department of Biology, University in Sarajevo.

Washington H.G., 1984 - Diversity, biotic and similarity indices: review with special relevance to aquatic ecosystems. Water Research, 18: 653-694.

Woodiwiss F.S., 1978 - Comparative study of biologicalecological water quality assesment methods. Second practical demonstration. Summary Report. Commision of the European Communities.

Woodiwiss F.S., 1980 - Biological monitoring of surface water quality. Summary Report. Commission of the European Communities. ENV/787/80- EN, 45 p.

Žganec K. \& Gottstein S., 2009 - The river before damming: distribution and ecological notes on the endemic species Echinogammarus cari (Amphipoda: Gammaridae) in the Dobra River and its tributaries, Croatia. Aquatic Ecology, 43 (1): 105-115. 